\title{
SOCIAL AGENCY INVENTING THE NATION: THE CASE OF RAHBANI BROTHERS, ABDEL HALIM CARACALLA \& THE LEBANESE FOLK DANCE
}

\author{
Jana Al Obeidyine \\ Choreomundus - International Master in Dance Knowledge, Practice, and Heritage \\ 1100, Beirut, Tarik el-Jadideh, Beaini street, Saneh building, Floor 2, Lebanon \\ E-mail: jana.obeidy@gmail.com
}

\begin{abstract}
Since the raise of postcolonial discourse, it has been difficult to look at folk dance groups in a none-western, 'developed' context without situating them in relation to the 'nationalist' project attributed to the West and the Soviet 'normalization' project. Through the specific case of the Lebanese Rahbani Brothers' theater and Abdel Halim Caracalla's dance theater, this paper aims to discuss the possibility of a theoretical framework that involves the role of individuals in the formation of social and cultural structures that is not utterly dictated, shaped and controlled by supreme and homogenous ideological, political or economic power. The paper relies, primarily, on the explanatory theory of Falsenecessity proposed by Roberto Unger.
\end{abstract}

Keywords: Rahbani, Caracalla, folk dance, nationalism, individual, false-necessity

If Rahbani Brothers and the diva Fairouz equal 'Lebanon' in the Middle East, Abdel Halim Caracalla equals 'Dance' in the Arab world. This paper aims to highlight the tremendous effect those individuals had on the conceptual formation of the words 'folklore' and 'dance' in Lebanon and the Arab world, while arguing that in some cases the conventional theoretical approaches to such phenomena do not necessarily lead to the best understanding of the society they belong to or represent. The first part of the essay will serve as an introduction to the Brothers, Caracalla and the resources used in this paper, whereas the second part will look at the impact of the contribution of those individuals to the dance and the dance scene in the Near East, arguing, in the last part, that the specificity and complexity of the Lebanese field call for a theory that 'seeks to free social explanation from its dependence upon the denial of our (as individuals) freedom to resist and to remake our forms of social life'. 'In other words, a theory based on Roberto Unger's concept of Falsenecessity, that by entails looking at the role of both institutional and individuals' power in the formation of social and cultural 'representations' or 'constructed realities'.

${ }^{1}$ UNGER 2001: 2. 


\section{INTRODUCTION}

In the beginning of the 1950s, Assi and Mansour Rahbani, along with the female vocalist, Fairouz, established operettas tradition and became the national symbols of the Lebanese State. At first, their operettas were based on rearrangement of traditional cultural items, such as stories, melodies, poetry. Later, their work ceased to be rooted in tradition and started to rely on artistic creation. After several productions, the team suceeded in dominating the artistic Lebanese scene and extended their activities to the Arab world. 'Consequently, not only is the Rahbani name familiar throughout the Middle East, North Africa and the Arabian Peninsula, but it has also dominated the theatre and music scenes in these regions for over fifty years; to Arabic speakers, the Rahbani name is as familiar as that of Shakespeare.' ${ }^{2}$

Abdel Halim Caracalla was a dancer and later a choreographer in the Rahbani theater. In the late 1960s, Caracalla left to London, where he undertook dance studies that implemented Graham modern dance technique. He came back to Lebanon and founded the first dance company in Lebanon and the Arab world in 1970.

The material used for the analysis in this paper relies on several academic essays that approach the work of the Rahbani brothers and Christopher Stone's book Popular Culture and Nationalism, the Fairouz and Rahbani Nation, written in 2001. Stone's book is one of the rare English contributions to Rahbani's work and exhibits extensive translated research materials while approaching their work through a textual analysis based on a post-colonial theoretical framework. On Caracalla Dance Theatre, however, there is no research available either in English or in Arabic; thus, the essay will rely on newspapers' articles, web pages and ethnographic material collected in Beirut, Lebanon within a city based folk dance group.

\section{DABKEH IN THE RAHBANI PRE-CIVIL WAR CONTEXT}

Dance is a fundamental element of the Rahbani Theater, specifically the Dabkeh, which is "the generic name for a kind of line dance that comes in many variant forms in the Levant and, under different names, in Turkey and Eastern Europe. Before the Rahbani Brothers came along, however, there was no such thing as 'Lebanon's Dabka' ${ }^{3}$. According to Stone the standardization of the Lebanese Dabkeh in the Rahbani's work was constructed upon the ex-soviet model of standardization of a unified national dance. Although, in form, the Rahbani line dance meets the description of the typical state folk dance ensembles of the twentieth century in terms of unified, coherent and crystallized movements, colourful costumes, dancers' athletic abilities and cheerful attitude. However, in content and in context, their Theatre deviated on two fundamental levels. Firstly, their work was neither funded nor monitored by the state (or an institution that represents the state). When their first play featured at Baalbek Festival, the first and most prestigious cultural event

\footnotetext{
${ }^{2}$ KHOURy 2008: 53.

${ }^{3}$ STONE 2008a: 65.
} 
in Lebanon funded by the private sector but reflecting the President ideology at the time of its establishment in 1956, 'none of the ladies of the committee (the festival committee was composed of only women ${ }^{4}$ knew what was going to be in the show'. Secondly, the predominant theme of their work was not that of the 'happy village' that characterized most of the state ensembles themes elsewhere but, rather, the divided village that would be reunited in order to achieve 'happiness'. Although, the theme emerges in their second production, after the events of 1958, a political crisis that occurred as a rebellion against the pro-western president, Camille Chamoun, it was, however, still a pre-war context. In a pre-civil war historical context, the theme seems to portray a social preoccupation rather than propagate a preconceived state ideology - which makes their Lebanon a future 'imaginative' state that has, yet, to be achieved. Therefore, their 'invented tradition' is forged in the 'imagined' past but it seeks its realization in the future. Moreover, although their first production was associated with Baalbek festival and its committee, Stone will, early in his book, announce that 'the signifying power of the Rahbani Brothers and Fairouz eventually breaks free, both literally and metaphorically, from Baalbek, and eclipses both site and Festival in terms of representational productivity's. In other words, Stone fills the gap between the conception of 'modern dance companies', where according to dance scholar Anthony Shay 'choreographies are created through a specific individual's aesthetic imagination, often representing that individual artist's emotional states, aesthetic interests, personal life experiences, and philosophical out-look' ${ }^{6}$ and that of state ensembles where 'the characters of the founder-artistic directors and choreographers are often more muted' to favour 'the "people's art", the pure spirit of the aesthetic expression of a specific ethnic group of people"7. The Rahbani built their imaginative world through their personal familial memories, that of their village, father and grandmother. ${ }^{8}$ Thus, what the Rahbani meant to Lebanese was equally the deliberate individual creativity and the 'art of people'. Especially that they were from a modest rural background, who worked as municipality officers ${ }^{9}$ before they started working at the radio station, where their artistic career debuted in 1950; hence, they were 'the people'.

\section{DANCE IN THE CARACALLA-CIVIL WAR CONTEXT}

Abdel Halim Caracalla started gaining international acclaim in 1978, three years after the breakthrough of the civil war in Lebanon, where the company was based and operating. That year the company toured with 'The Black Tents', a dance-play that features the rural life and traditions of Bekaa, or the valley of Lebanon. Like the Lebanon of the Mount featured in Rahbani's work, where villages are composed of 'red-tiled, stonewal-

\footnotetext{
${ }^{4}$ Femmes du monde.

${ }^{5}$ STONe 2008a: 41

${ }^{6}$ SHAY 1999: 54.

${ }^{7}$ SHAY 1999: 55.

${ }^{8}$ Stone 2008a: 37, 60, 65, 76, 77.

${ }^{9}$ The municipality officer character is omnipresent in their work
} 
led and old arch-replete houses', ${ }^{10}$ Caracalla' s village was inspired from his own, that of the valley with its historical desert black tents. Although, he continued, at the beginning, to portray the simple old days of rural Lebanon, his work would, soon, turn to celebrate the glorious ancient times with Elissa, Queen of Carthage (1996), Andalusia, the Lost Glory (1997) and Two Thousand and One Nights (2001). Caracalla's thematic can be easily viewed, compared and analysed from a post-colonial nationalism and orientalist perspectives. Nonetheless, the fact that in the late 1960s Caracalla left to England to undertake a Graham contemporary technique training, could make it also possible to look at his work as a part of the western modern dance movement, flourishing in Europe in the 1960s and the 1970s. Besides featuring tradition and reviving ancient myths appropriated to the geographical region, Caracalla adapted two Shakespearian plays, Midsummer Night's Dream (1990) and Much Ado about Nothing (1999). He, always, managed to end the performances with a long sequence of Dabkeh. Caracalla dance 'style' consisting of a modern technique shaped by oriental movements, such as stretched and strong female arm gestures combined with the freer wrists and hands gestures generating a fluid flow of movement. The verticality of their body is to generate a proud attitude without diminishing the waist, pelvis and hips curvatures. The same applies to male movements where stretched legs movements alternate with heavy 'pliés' providing a chauvinist attitude, accompanied by a wide-open and leading chest. Hence, Caracalla did not stick to the Moiseyev model and did not copy what he learned in England. He, instead, modelled a movement that he perceived as more representational of the region or its stereotype. However, blending the art of the east with that of the west was not a genuine feature of Caracalla's work. The blend started with the Rahbani folklorization endeavours and was considered to be a distinctive element of their work. Nevertheless, the genuine work Caracalla achieved on the Lebanese and Arab scene is the 'dance' itself. His company, which developed during wartime, was the first dance company in Lebanon and the Middle East and remained the only one for more than twenty years.

Being the first and only in a milieu that views dance as shameful activity, his company was the ultimate hope for Lebanese and Arab individuals who aspire for a dance career. The company succeeded in gaining the approval of the conservative Middle-eastern audience by featuring the dance, whether folk or hybrid, as a local 'high art'. Thus, dance that is not 'Rahbani-esque' (as folkloric) or 'Caracalla-esque' (as Arab modern) remained a dishonourable or mediocre undertaking. In other words, with them dance became a possibility.

\section{THEORETICAL SCOPE: THE EXPLANATORY THEORY OF FALSE NECESSITY}

According to the social theorist and politician, Roberto Unger, we, as social agents and researchers, are trapped in the constraint of the institutional and imaginative contexts that we, first, created. Which limit our freedom to act, rethink and reshape these contexts. ${ }^{11} \mathrm{My}$

\footnotetext{
${ }^{10}$ Stone 2008a: 76.

${ }^{11}$ UNGER 2001.
} 
argument is that the Lebanese social agent is, to a certain extent, free of such constraint in regards to its direct context with Lebanon due to the weakness of its institutional formation. Nevertheless, he is not immune to the constraints dominating the world that surrounds him.

Stone argues that the Rahbani Brothers were serving the French supported, Christian elite's idea of Lebanon in the 1950s, by diffusing a 'narrow Lebanon analogous to the Christian Mt-Lebanon village'12. Yet, he states, later on, that at the first meeting of the Brothers with Baalbek Festival committee - which is, to Stone, an institution-like organism - the ladies of the committee 'did not have a clear idea as to what they wanted to present there'13. He continues further to state that the "tension (between Rahbani and the committee) was [...] an issue of potential conflicting visions [...] to the version of Lebanon that would be presented there. ${ }^{14}$ Thus, since the beginning of the collaboration between the institution-like and the social agents, the institution seemed to lack 'vision', which allowed the Brothers a certain freedom of representation, leading them eventually to present a 'Christian Lebanese Mt Lebanon' that was, to them as individuals, the Lebanon they knew the most, as Christians from the Mount. Moreover, in a later work of Stone, entitled "Fayruz, the Rahbani Brothers, Jerusalem, and the Leba-stinian Song", Stone comes to the conclusion that the Rahbani project 'can [...] be seen as having been informed by their heartfelt work for Palestine, not the other way around"15. Politically and theoretically speaking, these propositions are paradoxical, since the two political projects that led Lebanon to fifteen years of civil war were, on one hand, the westernized Christian nationalist project, known to be hostile to Palestine and to be supported by the capitalist West. On the other hand, the Pan-Arabism project, a movement, first, initiated in Egypt, Lebanon and Syria by both Muslim and Christian Arabs against the Ottomans during the $19^{\text {th }}$ century and supported during the sixties and seventies by the communist East, that considered Lebanon as part of the Arab world and Palestine as common cause. Thus, if the Rahbani project was a nationalist state project, why, then, did it diffuse antagonist's political views of Lebanon? A possible answer to this question could be, as proposed earlier, that the brothers did not intend to promote a 'narrow Christian Lebanon', instead they, as individual artists, were simply inspired by their own lives and environment - which was neither to contradict their personal affiliation with Arabism, nor to restrain their sympathy towards the Palestinian cause.

Hence, if social agents have, already, a certain freedom, it is important that the theoretical scope, from which we attempt to understand the mechanisms of their social enactments, set them free from 'fixed divisions and hierarchies within humanity and [...] rigid rankings of subjective experience ${ }^{16}$. Looking at the Lebanese mosaic from the lens of social class, ethnic, religious divisions, will, probably, cause a fall into the trap of contradictions that shapes the society itself and will lead to more puzzling questions rather than explanations.

\footnotetext{
${ }^{12}$ Stone 2008a: 2.

${ }^{13}$ STONE 2008b: 30.

${ }^{14}$ Stone 2008a: 31.

${ }^{15}$ StOne 2008b: 164.

${ }^{16}$ UNGER 2001: 13.
} 
The breakthrough of the civil war in Lebanon is one major event, among other minor ones, in the history of modern Lebanon. On the concept of event, or conflict, Foucault asserts that 'structuralism formed the most systematic effort to evacuate the concept of the event, not only from ethnology but from a whole series of other sciences and in the extreme case from history ${ }^{17}$. Here is another reason why the 'deep-structure' theory, as Unger names it, seems to be less suitable in a context such as Lebanon. However, if the occurred conflict came to completely disable the Lebanese loose 'institutional structure', the 'imaginative structure' was to be disturbed.

According to Unger it is important to consider that the 'structure-disturbing and structure-inventing activity is not itself governed by a system of law-like constraints and tendencies, certainly not by the evolutionary logic or relentless practical imperatives ${ }^{18}$. Caracalla was not the only artistic case that broke with the Rahbani tradition, among others, there was Ziad Rahbani, the son of the Assi and Fairouz, pillar founders of the "green and beautiful imagined Lebanon". Ziad's theater, music and songs did not only break with his parents' world, but acted, in form, as 'antagonistic' to it.

Ziad's plays and songs, however, are heteroglossic reflections of Lebanon's fractured ethnic and class landscape, as enacted by the different accents of his actors. ${ }^{19}$ His representation of the Lebanon as diverse environment that 'may not be viable as a country' ${ }^{20}$ in a sarcastic fashion can be viewed as illustration of the daily lived civil war in contrast to the "imagined future Lebanon" his parents created.

Thus, the 'imaginative structure' built by the Rahbani Brothers was shaken, disturbed and re-invented during the war in, at least, two extremely different ways. Moreover, the chaotic, absurd, unstable environment of civil war and the total absence of institutionalism, which, in many cases, is expected to freeze if not deteriorate the productivity in all vital sectors, did not seem to have affected the cultural productivity in the Lebanese context. This is to say that questioning, rethinking, resisting and remaking social settings are not, necessarily, bound by a system that leads to fatal monotypic change.

More importantly, it is to be questioned whether a post-colonialist scope of theory is adequate to the Lebanese case. Since, although Lebanon was influenced by its cultural surrounding, especially the nationalist movement in Egypt, it is, however, doubtful that the social effects caused by twenty years of French mandate are comparable to hundred years of colonization elsewhere and certainly not comparable to four hundred years of Ottoman rule. In this case, it could be more relevant to build a post-Ottoman theory to reinforce the post-colonialist one and to add some post-communist thinking in order to be able to draw an understanding of the dynamics that shape the Lebanese social life. Since the mentioned systems of dominations do not share much in common as for the strategies, policies, tactics deployed in the course of their ruling. Above all, it is very crucial not to systemically consider Rahbani Brothers, Ziad and Caracalla as institutions. Although, their growth provided them with certain power over their social context, they remained social agents, who relied primary on their will in resisting, making and remaking their versions of Lebanon over time.

\footnotetext{
${ }^{17}$ Foucault 1980: 114.

${ }^{18}$ UNGER 2001: 4.

${ }^{19}$ Murphy - Kraidy 2003: 284.

${ }^{20}$ Murhpy - Kraidy 2003: 285.
} 


\section{CONCLUSION}

On one hand, established social theories are effective tools in the process of understanding social phenomena. However, assuming that one theory can draw a comprehensive understanding of these phenomena can, perhaps, lead towards a misinterpretation of the whole social setting. On the other hand, supposing the social agents are "mere puppets of (social) frameworks or of the forces that generate and sustain them ${ }^{21}$ or undermining their role in resisting, questioning and reshaping social realities may, possibly, lead to rigidity and stagnation in the theoretical interpretation. Thus, the effort to understand becomes less about understanding and more about categorizing or framing the social human behaviour. While the anti-necessitarian proposal of Roberto Unger does not discard the power exercised by 'institutional and imaginative' structures on social life, it acknowledges the ability of the social agency in reshaping and re-producing these frameworks, without, however, considering these processes as governed by 'rule-bound structure'22. Thus, it provides a ground to break with our habits of thinking in the prospect of a better understanding of extremely complex structured societies, such as Lebanon.

\section{LITERATURE}

Foucault, Michel

1980: Power/Knowledge: Selected Interviews and Other Writings, 1972-1977. New York: Vintage Books. KHOuRY, Yvette K.

2008: Akhir Yom (The Last Day): A Localized Arabic Adaptation of Shakespeare's Romeo and Juliet. Theatre Research International 33(1), 52-69.

Murphy, Patrick - Kraidy, Marwan M.

2003: Global Media Studies Ethnographic Perspectives. New York: Routledge.

SHAY, Anthony

1999: Parallel Traditions: State Folk Dance Ensembles and Folk Dance in "The Field." Dance Research Journal 31(1), 29.

STONE, Christopher

2008a: Fayruz, the Rahbani Brothers, Jerusalem, and the Leba-stinian Song. In: MaYer, T. - Mourad, S. (eds.): Jerusalem: Idea and Reality. London: Routledge. 155.

2008b: Popular Culture and Nationalism in Lebanon: the Fairouz and Rahbani Nation. London-New York: Routledge.

UnGER, Roberto Mangabeira

2001: False Necessity-anti-Necessitarian Social Theory in the Service of Radical Democracy: From Politics, a Work in Constructive Social Theory. London-New York: Verso.

${ }^{21}$ UNGer 2001: 4.

${ }^{22}$ UNGer 2001. 